Article

\title{
Crossing the Color Line: Black Professional Men's Development of Interracial Social Networks
}

\author{
Adia Harvey Wingfield \\ Department of Sociology, Georgia State University, Atlanta, GA 30302-5020, USA; \\ E-Mail: aharvey@gsu.edu; Tel.: +1-404-413-6509; Fax: +1-404-413-6505 \\ Received: 26 February 2014; in revised form: 7 May 2014/ Accepted: 13 May 2014/
}

Published: 22 May 2014

\begin{abstract}
Sociologists have established that social networks often play an important role in hiring, promotions, and occupational mobility. For black workers, however, social networks can be racialized in ways that work to their disadvantage. In this paper, I consider how black professional men develop and maintain interracial social networks with white men and women. I argue that these networks are shaped by intersections of race and gender and are intentionally constructed in response to black professional men's perceptions of their positioning within male-dominated occupations. Specifically, this paper examines how black men establish social networks with white men, their perceptions of how diverging levels of social capital shape these networks compared to their white male peers, and their observations of ways that women are less advantaged than they are in constructing social networks.
\end{abstract}

Keywords: social networks; black men; intersectionality

\section{Introduction}

While America is becoming an increasingly diverse nation, disturbing patterns of racial segregation still remain. Despite pronounced social and cultural changes that have occurred over the past several decades, the workplace continues to be one such site, where various social processes mean that racial minorities and whites are often separated and clustered into different jobs with varying levels of responsibility, prestige, status, and pay. Whites are overrepresented in professional/managerial jobs that convey greater salaries and opportunities for upward mobility, while blacks are more likely to be found in low wage, low status positions with fewer benefits, potential for growth, and responsibilities [1,2]. 
Black men and women employed in professional posts are still very much in the numerical minority in higher-status occupations.

Social networks play a major role in contributing to racial disparities that exist in jobs and labor markets. Many researchers have shown that social networks are racialized in ways that advantage whites while excluding blacks from key ties that could lead to information about and access to jobs $[3,4]$. These findings support the generally held contention that social networks tend to be intra-racial, with whites acting (often unintentionally) to reserve opportunities for other whites. Yet much less is known about the ways that workers develop interracial social ties once they are in particular jobs, and the ways that these networks can have an impact.

In this paper, I contribute to the existing literature by drawing attention to the processes and pathways by which interracial social ties emerge after employment. Focusing on a sample of nearly fifty black men employed in professional, white male-dominated settings, I examine the ways that these men establish social networks with white male and female colleagues. I argue in this paper that gender and race inform black men's sense of their positionality in these occupations, and influence both how they construct networks with white men and the ways they evaluate their social ties with white men relative to their white male and female colleagues.

\section{Literature Review}

Sociologists who study work have established that social networks are essential to developing and shaping access to certain jobs. Although positions may be advertised widely, simple applications are rarely enough to facilitate entry into jobs at the lower, middle, or top tiers of the employment ladder [5]. More often than not, social networks shape how individuals learn about jobs, whether they are recommended for employment, and the extent to which they are seriously considered as potential hires. In other words, social networks play a significant role in shaping various aspects of candidates' pathways into different positions. As Granovetter [6] noted in his classic analysis, inasmuch as social networks consist of ties between individuals, these connections may be strong or weak, with weak ties actually creating greater knowledge about work opportunities due to the more open flow of information through diverse channels.

Because social networks are so important, they have the potential to reproduce racial disparities. Taylor [7] has shown in his study of social networks among black leaders that links among this group are likely to be more tightly connected than those of their white peers. In the workplace, differential use of and access to social networks can result in racial minority workers being sorted into low-wage, low-status jobs or even excluded from consideration for certain positions [5]. More recently, in her classic work Race and the Invisible Hand, Royster [4] shows convincingly that white male vocational-education teachers differently utilized their networks, reserving the best connections, opportunities, and referrals for their white male students. Rather than passing opportunities to all students equally, black male students were excluded in ways that minimized their access to key jobs and reduced their employment prospects. White male teachers did not view themselves as acting in overtly racialized ways, but nonetheless hoarded opportunities for other whites.

Other studies continue to find evidence of these types of patterns. More recently, DiTomaso [3] found that while working, middle, and upper class whites stated their commitment to and belief in 
equal opportunity, they often acted in specific ways that undermined this in practice. One such pattern included similar processes of opportunity hoarding and reserving mention of job opportunities for white peers, colleagues, and friends. In other words, social networks were racialized in ways that created additional advantages for white job-seekers, while excluding black candidates for positions.

Social networks reproduce inequality in determining access to working class jobs [4,5], but this process occurs in professional job networks as well. In their study of black elites, Zweigenhaft and Domhoff [8] show that access to high status, high paying private sector positions is often preceded by attendance at elite private schools, membership in exclusive social organizations, and other types of connections that facilitate their knowledge of and entry into these jobs. The social networks that are formed in these settings help to build the social and cultural capital that eases black workers' entry into or maintenance of their elite standing.

These studies show that social networks are critical for developing access to professional and nonprofessional jobs. However, the ways that individuals utilize these networks can easily lead to the reproduction of racial disparities in the labor market and within jobs, wherein black workers find their access to the most sought-after positions minimized as whites reserve information and utilize their networks in ways that benefit other whites [3-5,8]. In this paper, I take a different direction and examine the ways that social networks are developed and maintained once black professional workers are established in their positions.

\section{Black Professionals and Social Networks}

For black workers in professional environments, developing social networks can be a daunting process. This is due to the fact that these employees face a number of challenges that can undermine their attempts to develop these critical ties. Though conventional wisdom would suggest that ascension to work in professional/managerial occupations would relieve black workers of race-related difficulties, extensive sociological research suggests otherwise. Thus, black employees' ability to develop essential social networks once in the workplace are likely affected by a number of social processes that operate to their disadvantage.

Discrimination is one such process that can undermine black workers' ability to establish social networks when employed in professional settings. In his study of racial and gender discrimination at work, Roscigno and his associates [9] find that black workers are subjected to various factors that in many cases make their work experience impossible. Using data from the Ohio Civil Rights Commission, they find that undue termination, selective enforcement of rules, and racialized workplace harassment are often commonplace for black employees. These incidents likely make it much more difficult for these workers to develop the social networks that are so important for upward mobility.

In addition to processes of discrimination, marginalization is another factor that works to black employees' disadvantage establishing networks. Researchers find that black employees often experience isolation and exclusion, particularly in predominantly white fields [10-12]. As a consequence of this alienation, black workers may find themselves with weaker ties to colleagues, particularly those whose influence matters in facilitating long term ties to the organization or the 
profession [13]. Thus, the social isolation black employees face in predominantly white workplaces, particularly in professional occupations, also creates difficulty forming social networks.

Taken together, this research suggests that social networks are key for facilitating access to job opportunities and remain important once workers are employed in their positions. However, these networks often reproduce racial hierarchies, with black workers frequently excluded from the flow of information and resources that whites pass along to other whites [3]. The social processes that black employees encounter at work can make the development and maintenance of these networks even more difficult.

The research on black professionals, however, tends to treat jobs as monolithic without giving due consideration to the ways that the gender of the worker and the gender composition of the job in which they are employed could potentially have an impact on the formation of social networks. Due to the persistence of occupational sex segregation [14], women and men still tend to work in predominantly female or male-dominated jobs. Thus, when black professionals encounter issues with marginalization, discrimination, and social isolation that adversely affect their ability to establish viable social networks, they are likely to contend with these processes in jobs where they are in the racial but not the gender minority. In other words, black professional women are concentrated in female-dominated jobs where they may be the only black woman employed among many other women, and black men face parallel dynamics as they are likely to experience these racial dynamics in occupations comprised mostly of men.

In this paper, I argue that the gender composition of jobs matters in shaping the ways that black workers develop social networks in professional positions. Though it has not been extensively studied, I contend that when black workers are in the racial minority and gender majority at work, these dynamics have an impact on the ways that interracial social networks are developed and sustained. Specifically, in this paper I focus on the ways black professional men develop interracial social networks when they are employed in white male-dominated occupations. The core questions guiding this research, then, are: how do black professional men establish interracial social networks in this context? How do their networks differ based on gender?

\section{Research Design/Methodology}

In order to examine the ways that intersections of race and gender impacted black professional men's tokenization, I relied on semi-structured interviews with 42 black men employed as doctors, lawyers, bankers, or engineers. Intensive interviews were selected for the methodology because they allowed respondents to speak in extensive detail about various aspects of their work experience. Thirteen respondents were lawyers, twelve were doctors, ten were engineers and seven were bankers. As such, they were employed in occupations where black men constitute a very small minority of workers. All respondents noted that most of their employment history involved working in environments where they were the only black male at their occupational level, or one of two or three. The majority of their colleagues were white males, though three engineers described working with a handful of Asian American men, and all of the lawyers identified between 1-3 women who were associates at their firms. Thus, these men's work environments reflect recent data indicating that these 
four occupations are predominantly white male-dominated (See Table 1), while support staff (e.g., nurses, legal assistants, administrative assistants) are mostly white women.

Table 1. Percentages of males employed as doctors, lawyers, engineers, and bankers.

\begin{tabular}{cccccccc}
\hline \multicolumn{7}{c}{ Males in Professional Occupations 2000 Census Data } \\
\hline & $\begin{array}{c}\text { Total } \\
\text { Male }\end{array}$ & $\begin{array}{c}\text { Black } \\
\text { Males }\end{array}$ & $\begin{array}{c}\text { White } \\
\text { Non- } \\
\text { Hispanic }\end{array}$ & Hispanic & $\begin{array}{c}\text { Asian } \\
\text { Non-Hispanic }\end{array}$ & $\begin{array}{c}\text { A. Indian/ } \\
\text { Alaska Nat. } \\
\text { non-Hispanic }\end{array}$ & $\begin{array}{c}\text { Hawaiian N. } \\
\text { \& Pacific Is. } \\
\text { Non-Hispanic }\end{array}$ \\
\hline Physicians/Surgeons & $81.2 \%$ & $2.6 \%$ & $55.9 \%$ & $3.7 \%$ & $9.8 \%$ & $0.1 \%$ & $0 \%$ \\
Lawyers & $71.3 \%$ & $2.0 \%$ & $65.0 \%$ & $2.0 \%$ & $1.2 \%$ & $0.1 \%$ & $0.0 \%$ \\
Engineers * & $84.5 \%$ & $3.0 \%$ & $73.3 \%$ & $3.7 \%$ & $12.1 \%$ & $0.3 \%$ & $0 \%$ \\
Bankers ** & $46.6 \%$ & $2.5 \%$ & $83.2 \%$ & $4.8 \%$ & $5.1 \%$ & $0.3 \%$ & $0.1 \%$ \\
\hline
\end{tabular}

EEO Residence Data Results for Total US from the US Census 2000; * Engineers include aerospace, chemical, civil, computer hardware and software, electrical and electronic, environmental, industrial, material mechanical, and nuclear engineering; ** Bankers include loan counselor/officers, financial specialist/all others, personal financial advisors, financial analysts, credit analysts, accountants and auditors, and financial managers.

Respondents ranged in age from 33 to 60. All held at least a college degree, with all lawyers and doctors holding terminal degrees in their fields (JDs and MDs, respectively). Four of the ten engineers interviewed held doctorates, two more were working on postgraduate degrees, and two bankers had earned their MBAs by the time of the interview.

Respondents were located through a snowball sample. Using a combination of referrals from professional organizations like the Georgia State Bar Association and the National Society of Black Engineers as well as from personal contacts, the author was able to locate black men who fit the criteria for this study. Interviews generally lasted one to two hours and took place in the respondent's office, the author's campus office, or in a neutral location such as a coffee shop or bookstore. With only one exception, respondents consented to be tape recorded during the interviews. In the case of the one exception, the author took copious notes to capture the substance of the interview. All interviews were transcribed and analyzed, and all names and identifying details have been changed in this paper to protect respondents' privacy and anonymity.

It is also important to consider the ways the interviewing author's own racial and gender status may have shaped the interview dynamics. As an African American woman interviewing black men employed in professional contexts, race and gender undoubtedly informed aspects of the interviewerrespondent relationship. It is quite possible that respondents felt some degree of commonality with the author due to the shared racial status and positioning as workers in professional, predominantly white environments. Yet it is equally possible that gender also affected the interview dynamic by shaping what male respondents were willing to share. However, other female researchers who study men's experiences at work have noted that one key advantage of the intensive interview format is that it enables male respondents to clarify and diplomatically phrase comments and answers so that they can answer honestly while avoiding words and phrases that may be construed as sexist or offensive $[15,16]$. As such, while gender may have informed the way men replied to questions, the intensive interview format hopefully allowed them to give honest answers even if they were prefaced by phrases such as "this might sound sexist, but...". 
Interviews began with basic demographic questions about respondents' ages, educational backgrounds, areas where they were born and raised, and factors that influenced their interests in their chosen career fields. This is a fairly common technique with intensive interviews because it eases the respondent into the interview format [17]. Questions then broached respondents' work histories in their current jobs, career aspirations, relationships with colleagues, levels of job satisfaction, and whether respondents ever witnessed or were aware of any tensions that existed in the workplace related to issues of race and gender. In asking questions this way, respondents were able to offer a broad overview of various aspects of their workplace. The framing of these questions also allowed respondents to share on their own whether they felt that issues of race and gender were challenges they faced in the workplace, without assuming this to be the case. Most relevant for this paper, respondents were asked whether developing relationships and networks with colleagues and supervisors was necessary for job success, if they were able to develop such relationships, how those networks emerged, and whether they felt there were factors that made it easier or harder for them to construct these ties relative to other coworkers.

Concurrently with data collection, interviews were analyzed using NVivo 9, software specifically designed for qualitative data. This software allows researchers to extract common themes, narratives, and concepts that emerge from the data and to code them accordingly. As such, data were coded by themes that emerged deductively, such as supportive relationships with women vs. suspicions of women as unduly advantaged; access to social networks vs. difficulties developing ties to mentors; or restrained emotional performance at work vs. comfort displaying anger, frustration, and other feelings that may be concealed in professional environments. Based on this analysis, I was able to develop a narrative that illustrated various aspects of black professional men's work experiences, including the ways that they were able to construct social networks with white men and women. All responses discussed in the next section refer to the ways black professional men established these interracial social ties with white colleagues.

\section{Findings}

The data indicate that black men working in professional environments are able to form viable, helpful social networks with whites. These networks engender the flow of information about potential jobs and possibilities within the organizations where they are currently employed. However, they also differ markedly by gender. Black men's social networks with their white male peers, colleagues, and supervisors were marked by implicit contrasts between their own experiences and those of their colleagues. Conversely, when black men established networks with white women, these were often shaped by an interest in undermining gender-related challenges these men identified as existing for women of all races in male-dominated occupational fields.

\subsection{Social Networks with White Men}

Many respondents described having social networks that included white men. Jared, an engineer, talks about the need to have interracial social networks and why his white male mentor has been particularly invaluable: 
"For me and probably a lot of African Americans, we can't lean on a family member who has had a similar experience and say "Dad was teaching at whatever." So on either side of my family, as far as we know, I'm the only doctorate, ok. So, therefore I'm the only professor. So, there's certain sort of rules of thumb, learning the ropes; there's certain tricks of the trade that I have to get from the job or colleagues here. There's no family I can go "oh yeah, tell me about it." Even depending on how, as a grad student, your advisor is in sharing things, [you may not learn]. So, in that sense it was important to have somebody who was more experienced, whom I could trust, that I could go to and say "hey, what about this, what about that." So, yes, so it's been helpful in terms of just helping my performance and what I'm doing and that sort of thing.

Here, Jared compares the lack of social capital that exists among his family members and compares that to the level of experience and knowledge his white male mentor has. For him, developing interracial social networks with white male peers is critical to professional success.

Lawrence shares a similar story. He is a doctor at a major hospital who also counts a white male mentor as one of his critical allies. He states:

He actually helped recruit me here and said, I want you to help grow and develop this department, those kinds of things...He looks out for me and does the things that you want a mentor to do - sort of look for opportunity, feedback, I'd do this differently and this kind of thing, and be honest and open about it.

Similarly to Jared, Lawrence describes a specific example of social ties to a white male supervisor who functioned as a mentor and helped promote his career advancement. He gives a concrete case of building on his interracial social networks.

For black professional men, developing social networks with their male peers often was a gendered process that they were able to enact relatively easily. In response to questions about how men were able to form social ties with white male colleagues or supervisors, virtually all respondents described capitalizing on shared pastimes and hobbies that enabled them to develop social ties and relationships with their white male peers. Often these were culturally masculinized behaviors that gave men a way to create inroads across racial barriers that might have existed in the workplace. Thus, gender solidarity facilitated the development of these men's interracial social networks.

Lars, an engineer, spoke specifically to this issue. He argued that relative to his women counterparts, he probably had an easier time bonding with male colleagues:

"At some point men relate to each other on a certain level. You know, once they feel comfortable. We have some way of relating to each other. But for a woman it's more difficult to kind of relate to a man, so they don't even have that to rely on. We can talk about sports or something that's kind of quote unquote, male, that women don't really have that area."

For Lars, this ability to talk about sports and other stereotypically masculine interests engendered social networks that crossed racial lines. Despite working in a predominantly white career field, he was able to rely on gendered interests to create useful links with other white male workers. 
Roger, another engineer, also describes how gendered activity facilitates relationships with white male colleagues. In response to a question about how he was able to develop these networks, he stated:

One of them, through working out. I work out with an associate dean. We work out every morning and we talk every morning and have coffee together in the morning. And that's one of the differences betweenthe advantages that men have [compared to women], like just working out.

While Lars identifies sports as a gendered bonding activity, Roger notes the ways that the gendered organization of exercise, an otherwise neutral activity, facilitates the creation of interracial social networks. In addition to using the gym and exercise facilities, separate locker rooms for men and women give him an exclusively male space in which to interact with the dean and build the networks that are so critical for advancement and upward mobility in these jobs.

Kwame, an attorney, makes a similar remark in discussing the relative ease that black male workers have in forming social networks with their white male peers. He states:

Based on where we are in the United States of America and to a degree, to a degree being a male that's probably in some instances it's even to an advantage. Because some guys feel more comfortable dealing with males. And I can see where women get the short end of the stick at times.

Like Lars, Kwame identifies how gender serves to make the development of interracial social networks easier, particularly relative to women peers. As men, these respondents feel that gender provides a level of comfort and solidarity that helps with the formation of these types of ties.

Kris, another respondent, described ways that overwork based on the marginalization of women led to interracial social networks with white male colleagues. As a doctor, Kris was in an environment where lengthy, grueling work hours were commonplace. He contrasts his experiences working those type of hours with that of a former female colleague:

I was on a rotation with a girl who was pregnant and she was very special and my friend, but she would ask to go home every night at eleven. That's unheard of but she was pregnant. She was really tired. I said "look, you do your patients early I'll let you go home". That's unheard of. But when she left we would all get together and go, "Now the real work begins, guys. Let's go on and stay up until four in the morning and see the patients and talk about stuff and this and that. So the guys get their camaraderie out of watching the women go home early and criticizing them. So that makes you feel better staying up till four.

Kris's remarks show again how gender solidarity becomes a pathway towards interracial social networks between black and white male workers. Interestingly, this process he describes of men characterizing overwork as indicative of masculinity has been identified in other studies [18]. What is significant about Kris's response is that he underscores how this type of gendered understanding of work - and in particular, extremely long hours associated with being a physician - become a route through which black men develop ties to their white peers. Thus, this process is not only a way of feminizing (and stigmatizing) flexible work arrangements, but in addition to sports and exercise, 
functions as a way of masculinizing punishing work hours as a means of developing social ties between men of different races.

It is also important to acknowledge that for a majority of these respondents, their perceptions of their social networks were cast in relation to those of their women counterparts. That is, men often stated that even relative to their white female colleagues, they had fewer challenges developing social networks with the white males who constituted the majority of their coworkers. This is an important point, because it indicates that while these men felt that they could create interracial networks with other men more easily than women, this was a very particular reference point.

Black professional men's sense of the social networks that white men were able to form with other white men provide an interesting contrast. While they noted that they could form interracial social networks with white men more easily than their white women colleagues, they also contended that the networks they were able to form were more tenuous and offered less potential for advancement than the social networks they observed among white men.

\subsection{Comparisons to White Men's Social Networks}

While respondents saw their own networks with white men as driven by gendered dynamics that made them easier to procure than those women were able to establish, they also perceived that white men's networks with other white men were more effective, useful, and advantageous for upward mobility and occupational advancement. In understanding black men's sense of their social networks with white men, it is important to put these in the broader occupational context of the ties that they believe other workers have and the ways those relationships facilitate opportunities at work.

Ricky, an attorney, spoke at length about the importance of social networks in establishing a career as a lawyer. Since generating business is a central component of partnership, relationships take on critical importance in enabling (or discouraging) black male lawyers' opportunities for promotion within firms. He contrasts here the differences between black and white men's social networks and how they affect the ability to build a "book of business":

If you've developed a book of business, it's yours. You've developed it. You've nourished it. You've gone out and beat the bushes and brought it back. Didn't nobody give it to you. Didn't nobody assist you in getting it. That's your baby. And I certainly understand and respect the black men that I've worked with over the years and they work hard. Whatever client they had, didn't nobody give it to them. They had to go out and hustle for it, compete for it and they landed it. White cats: there's this fellowship, there's this cronyism, there's this understanding "what's mine is mine and yours" sort of speak. You know, I'm going to go out here and get this piece of business, by the way, when I get it, I'm going to give you a little piece of it. And when I'm gone, I'm going to pass it on to you and then you can pass it on to some folks and we're going to work this thing and do better, collectively do it. [In contrast, for black men, it's] Brother, you going to do it all yourself. You're going to do it by yourself. You're out there by yourself.

Ricky points out here that while black men in his field work very hard - and often in isolation- to develop the contacts and ties that will enable them to enjoy successful careers in the legal field, the 
relationships and networks that exist among white male lawyers often make establishing this book of business somewhat easier. He describes stronger ties among these men than those that exist between black men and white men.

Wallace, another attorney at a major firm, makes a similar point about the difficulties building this book of business and how social networks play a role:

My challenge is not kind of within the firm, the challenge I see as a black man is in the legal community in terms of clients, that sort of thing... Most business relationships are based on the relationship. And a lot of them are based clearly on friendship, or social relationships. The rest of our quote unquote rainmakers, it's not because they're the best lawyers, they just have friends, they just happen to have their best friends as the GC of this company or their best friend is the CEO of this company. So that opens up business for them and they are seen as more valuable. I mean in terms of bringing dollars in the door. And that's where you see the challenge. Because my social network prior to now arriving, doesn't include any people that fit that description. I didn't grow up with anybody who's the CEO somewhere. And my colleagues in college, and I tended to not branch out as much as I should have, and so it's mostly a circle, up until I get to my professional career, of all black people who are again less likely to be in the decision making role. My client base is Fortune 100, so I'm not dealing with $\mathrm{X}$ Company. They don't grow prior economics, the big boys. They're not plugged in to those companies. So I don't have those, a connection that I see some of my peers having and able to have, hit the ground running. [The challenge exists] from a client perspective where I'm grinding and trying to build those relationships and doing a whole lot of networking and stuff to try and get there.

Wallace eloquently highlights the distinctions between the types of networks he is able to formulate (and the limitations that created them), and those of his white male peers. He had recently made partner in his firm prior to our interview, and described having very strong, solid relationships with his male colleagues that were integral in his path to partnership. Yet as he observes here, from his perspective these networks are not equivalent to those of his white male colleagues who are much more likely to enjoy social relationships with high status individuals who can then become clients of the firm and allow the attorneys to bring in significant financial rewards, thus becoming rainmakers.

Farley, a banking executive, also speaks to the contrasts between the social networks he is able to establish with other white men and those white men hold with each other. Discussing how his early experience in an MBA program mirrored the types of social patterns he encountered later in his career, he states:

Whereas I finished number three in the class, I fell to the bottom in terms of plum assignments [because] I didn't have a mentor, or a sponsor. And whereas my division manager had recommended me to go, he saw potential but he didn't necessarily take me under his wing as his chosen guy. I wasn't a golden boy. So all these other guys who I'm helping them out at night, helping them get through, they had been kind of selected, or pre-selected to go to the school, so they were going to come back to these assignments that had been slotted for them. They just needed this last test or this last checkmark for them to get slotted into these great positions. Whereas I had come back and had achieved but didn't 
have anything slotted and didn't have that mentor, so it was two things [I learned]. One, I got to get me a mentor, or somebody who's going to raise my banner for me. And then the other piece was that even though, you can be smart, you can have the right set of credentials, and as long as you're the right schools you still have to work that network from the perspective of making sure people know not only your ability, but you know in terms of having some kind of social piece.

Farley describes clearly here how being smart and in the "right" MBA program was not enough. Without the types of networks that he saw among his white male counterparts, he could not be assured of a job or long-term success in the field.

Ultimately, black professional men's perceptions of white men's networks with each other offers an important context in which to understand their descriptions of their interracial networks with other white men. The responses shared here evince a common pattern wherein many black men reported feeling satisfied with the relationships they were able to develop with their white peers, and reported that gender made it easier for them to create these networks, they still contextualize these networks relative to their white male counterparts. In other words, gender and race become critical dynamics that influence the ways black professional men interpret their networks with white male colleagues. Respondents see themselves positioned in such a way that gender benefits them relative to women colleagues, but does not completely posit them as the equal to their white male peers.

\subsection{Social Networks with White Women}

While gender structures black professional men's perceptions of their social networks with white men and those of white men with each other, it is also a factor that influences how they describe their interracial, cross-gender social networks with white women. Black professional men may compare their ability to establish networks favorably to those of white women, but in about a third of the cases, they also describe developing networks with white women that are grounded in their perceptions that gender gives men an advantage in male-dominated occupations.

Several respondents spoke of their perception that the male-dominated culture of their jobs created additional difficulties for women workers employed in these professions. Felton, a banker, described his industry this way:

I mean it's tough from a women's perspective because it's a male dominated business. Very few women are necessarily looked at as peers and then the family piece kicks in. You know, are you going to have a career; are you going to have family. And those women that choose not necessarily to take the family route first, you know, there are all kind of negative connotations that are, you know, given to them in terms of are you going to be career oriented.

Felton identifies gendered perceptions about women and family that adversely affect women's career tracks and have been noted by other researchers studying challenges women face in the workforce [19]. This sense that banking is a more difficult field for women helps establish a context that shapes the ways men establish social networks with women peers. 
For some respondents, the sense that they experienced challenges that paralleled those of their women counterparts was a critical motivating factor that shaped the networks they established with women. These men described taking active measures to include women in their networks, particularly if doing so was likely to lead to more visibility or greater opportunities for these women. They thus took intentional steps to create interracial, cross-gender networks that included white women out of a sense of shared (albeit differently structured) experience of minority status.

In one statement to this effect, Andy describes his deliberate decisions to construct his social networks to be a mentor to women coworkers:

I sympathize 'cause I understand the issue and I can look at the numbers and tell that women aren't being as successful as white men. So there's a solidarity in the sense that if there were two people, similarly situated with same credentials, both could offer me the same things in a project, I would pick the woman just because inherently in my mind, I'm thinking if I don't do it things aren't going to change.

Andy is a partner at a law firm and thus is very aware of the role senior attorneys play in mentoring more junior associates. Consequently, it is important to him to make sure that women are included in his network of potential mentees. This is a particularly salient point for Andy, who noted elsewhere in his interview a common theme echoed by other black male attorneys about the challenges finding senior partners willing to provide mentorship. For Andy, this experience becomes something that motivates him to provide more guidance to women lawyers by proactively including them in his networks.

Lars, the engineer mentioned earlier, talks about developing social networks that specifically include white women so that he can provide social support that counters the hegemonically masculine environment they may encounter in this field:

A lot of times, cause I can feel their pain. And this is black women, also white women. I'll talk more with them. Some people will just start shunning them, or something goes on and you see people talking...then for instance Jane says, I think there are duplicate files in the directory or something. And people [make] little smart [comments]. So I can feel that. It speaks to just - it's a form of disrespect. But it has more to do with the fact that they're female. So I may be more engaging in terms of saying, trying to cut through the nonsense of all the jokes or whatever and say 'hey, let me help you'. Or maybe I'll say "here's what I think it is." And then I'll say something that I know makes no sense and they're looking at me like what is he talking about, and then she can recover and say "no I tried that." You know what I'm saying? Build some sort of credibility.

Lars sees engineering as a "boys' club", and describes relating to the isolation that women may feel in this environment due to his status as a black male and the marginalization that he encounters at times. Consequently, he makes sure that his white women peers are part of his networks so that he can help create a more comfortable work environment. This way, when women are treated in a condescending fashion, he can take steps to help them retain some standing among their peers.

Ultimately, these respondents indicate that their perception that women face a less welcoming environment in occupations with a decidedly masculinized culture helps to inform the ways that they construct social networks. Believing themselves to be in a relatively privileged position compared to 
their female counterparts, black professional men are thus motivated to establish interracial, cross-gender networks with their white women peers. In feeling that they occupy a marginal status where they have greater occupational advantages than their female colleagues, but lack parity with their white male peers, these respondents create social networks that include white women in some cases with the explicit intention of leveraging their gendered status in such a way that it might help to create a more equitable work environment.

\section{Conclusions}

This study demonstrates that for black professional men, the process of developing interracial networks is shaped by both race and gender. Black men assert that gender enables them to construct social networks with their white male peers relatively easily, particularly compared to their female colleagues. However, they also find that these networks are lacking relative to those of their white male peers, who they observe having ties that are much more likely to facilitate occupational rewards and advancement. Gender also informs the ways black professional men form networks with white women colleagues, in that men sense that the gendered culture and character of their occupations creates additional difficulties for women, so they often pointedly include women in networks to help leverage the advantages they enjoy as men in these male-dominated jobs.

This study thus makes a contribution to the literature on social networks by highlighting the ways that gender matters in constructing interracial social networks, both in terms of the worker and composition of the occupation. Specifically, gender helps to mitigate some of the ways that processes of discrimination and marginalization could hinder black professional men's attempts to form interracial networks with their male peers. Despite being in the racial minority, their shared gender identity puts them in a better position than their female colleagues to develop networks with white men. This is not to suggest that these respondents do not describe perceptions of discrimination and isolation in these jobs (see [20]), but they do indicate that relative to their women peers, gender is a more dominant factor that works to their advantage in helping them to establish interracial social networks with white men.

Gender also informs the ways that respondents construct intraracial, cross-gender social networks. Due to their perceptions that women face greater challenges in these male dominated occupations than they do, black professional men are often motivated to welcome women into their social networks and actively take steps to ensure that they are included. Yet this is driven by the gender composition of the jobs in which men work, and suggests that when black men work in male dominated fields, they may be more comfortable making women part of their social networks.

Based on this study, respondents do not report that personally experiencing marginalization and discrimination in the ways that are described in the existing literature shape the degree and extent to which they form interracial networks. Rather, their status as minority men working in male-dominated occupations is described as a critical factor that influences the types of networks they build with white men and women. Working with other men helps respondents form ties to white male peers more easily than their female counterparts, yet these networks remain racially constructed and do not rival those of their white male colleagues. Additionally, recognizing the gendered advantages they enjoy in these professions pushes black men to make it a point to construct networks that include women. Unlike the 
research which describes the ways black professionals are likely to encounter discrimination and marginalization that could impede interracial social networks $[9,11]$, this study suggests that black professional men's awareness of the ways that their women counterparts might experience these processes actually makes them more likely to include women in the networks they develop.

The finding that respondents cite gender, more so than discrimination or marginalization, as a key factor shaping their interracial social networks is also an important contribution to the existing literature on black professionals. Much of this research either documents the ways opportunities for black professional workers are vulnerable [21-23], or highlights the ways in which fractious or strained relationships with white colleagues curtail occupational mobility $[10,24,25]$. By no means do my findings suggest that these issues do not exist, but the results of this project contribute to this literature by demonstrating other social factors that have an impact on black professionals' work lives.

Research has been slow to consider the development and maintenance of interracial social networks in professional work environments. This study points to the need for future work that considers how gender contributes to the ways these networks emerge, both in terms of the gender of the workers in the networks and the composition of the jobs in which they are employed. Interracial social networks between black and white women, for instance, may reflect the influence of gender and race in different ways, particularly depending on the gender composition of the jobs in which these women work. In other words, future studies would have to determine whether black women who work in female dominated jobs find that they can form social ties with their white women colleagues more easily than their male counterparts can, as well as whether this leads them to include black men in their networks. Unlike black men in this study, they may be less likely to rely on male-typed activities such as sports as a tool for establishing social networks, perhaps finding instead that other culturally feminized activities may prove more effective.

Future research might also consider whether there are possible drawbacks for minority men (and potentially women) as a consequence of structuring these interracial social networks. Most respondents in this study cited the construction of these social ties as processes that were beneficial and helped them navigate predominantly white work environments more smoothly and easily. However, it is worth considering whether developing these networks could also have disadvantages, perhaps by alienating black workers from each other or fostering intraracial competition.

Another direction for future studies would be to assess the extent to which such networks have concrete outcomes for black workers. Respondents share their perceptions that they are able to build same gender, interracial networks relatively easily, and that they are motivated by perceptions of commonly shared marginalization to construct cross-gender, cross racial networks. However, it would be important for studies of race, gender, and work to consider whether and how such networks lead to measurable improvements in occupational status and mobility. It is beyond the scope of this study to determine if these networks extend to middle or upper management levels (though the existing data suggests that this may be the case). Future research might address whether these social networks foster advancement into and continue when black men are employed in managerial roles.

Ultimately, this project helps to shed light on the ways interracial same-gender and interracial, cross gender social networks are constructed. The results here help us to understand better how these networks develop and the important ways that they are gendered. Hopefully this study will give rise to 
future research that continues to examine the role gender plays in shaping interracial networks in other work settings and among other racial groups.

\section{Conflicts of Interest}

The author declares no conflict of interest.

\section{References}

1. Stainback, K.; Tomaskovic-Devey, D. Documenting Desegregation: Racial and Gender Segregation in Private Sector Employment Since the Civil Rights Act; Russell Sage Foundation: New York, NY, USA, 2012.

2. Tomaskovic-Devey, D. Gender and Racial Inequality at Work: The Sources and Consequences of Job Segregation; ILR Press: Ithaca, NY, USA, 1993.

3. DiTomaso, N. An American Non-Dilemma: Racial Inequality Without Racism; Russell Sage: New York, NY, USA, 2013.

4. Royster, D. Race and the Invisible Hand: How White Networks Exclude Black Men From Blue-Collar Jobs; University of California Press: Berkeley, CA, USA, 2003.

5. Kirschenman, J.; Neckerman, K.M. We'd Love to Hire Them, But...The Meaning of Race for Employers. Urban Underclass 1991, 203, 203-232.

6. Granovetter, M. Strength of Weak Ties. Am. J. Sociol. 1973, 78, 1360-1380.

7. Taylor, H. The Structure of a National Black Leadership Network: Preliminary Findings. Unpublished work, 2002.

8. Zweigenhaft, R.; Domhoff, G.W. Diversity in the Power Elite: How it Happened, Why it Matters; Rowman and Littlefield Publishers, Inc.: Lanham, MD, USA, 2006.

9. Roscigno, V. The Face of Discrimination; Rowman and Littlefield: Lanham, MD, USA, 2007.

10. Bell, E.; Nkomo, S. Our Separate Ways; Harvard Business Press: Boston, MA, USA, 2001.

11. Feagin, J.; Sikes, M. Living with Racism: The Black Middle Class Experience; Beacon Press: Boston, MA, USA, 1994.

12. Paap, K. Working Construction: Why White Working-Class Men Put Themselves and the Labor Movement in Harm's Way; Cornell University Press: Ithaca, NY, USA, 2006.

13. Pierce, J. 'Racing for Innocence': Whiteness, Corporate Culture and the Backlash Against Affirmative Action. In White Out: The Continuing Significance of Racism; Doane, A., Bonilla-Silva, E., Eds.; Routledge: New York, NY, USA, 2003.

14. Charles, M.; Grusky, D. Occupational Segregation: The Worldwide Segregation of Men and Women; Stanford University Press: Redwood City, CA, USA, 2004.

15. Britton, D.B. At Work in the Iron Cage: The Prison as Gendered Organization; New York University Press: New York, NY, USA, 2003.

16. Williams, C. Still A Man's World: Men Who Do Women's Work; University of California Press: Berkeley, CA, USA, 1995.

17. Berg, B.L. Qualitative Research Methods for the Social Sciences, 3rd ed.; Allyn \& Bacon: Boston, MA, USA, 1997. 
18. Kelly, E.; Moen, P.; Tranby, E. Changing Workplaces to Reduce Work-Family Conflict: Schedule Control in a White Collar Organization. Am. Sociol. Rev. 2011, 76, 265-290.

19. Kmec, J. Are Motherhood Wage Penalties and Fatherhood Bonuses Warranted? Comparign Pro-Work Behaviors and Conditions of Mothers, Fathers and Non-Parents. Soc. Sci.Res. 2011, 40, 444-459.

20. Wingfield, A. No More Invisible Man: Race and Gender in Men's Work; Temple University Press: Philadelphia, PA, USA, 2013.

21. Collins, S.M. Black Corporate Executives: The Making and Breaking of a Black Middle Class; Temple University Press: Philadelphia, PA, USA, 1992.

22. Wilson, G.; Roscigno, V.; Huffman, M. Public Sector Transformation, Racial Inequality and Downward Occupational Mobility. Soc. Forces 2013, 9, 975-1006.

23. Wilson, G. Starting the Same...Finishing the Same? Race, Occupational Origins and Mobility Into Managerial Positions. Am. Behav. Sci. 2012, 56, 682-695.

24. Wingfield, A. Racializing the Glass Escalator: Reconsidering Men's Experiences with Women's Work. Gend. Soc. 2009, 23, 5-26.

25. Kaplan, V. Structural Inequality: Black Architects in the United States; Rowman and Littlefield: Lanham, MD, USA, 2006.

(C) 2014 by the author; licensee MDPI, Basel, Switzerland. This article is an open access article distributed under the terms and conditions of the Creative Commons Attribution license (http://creativecommons.org/licenses/by/3.0/). 